Paweł Warchoł ${ }^{1}$

Papieski Wydział Teologiczny w Warszawie

\title{
Ślady Boga w przyrodzie w pismach świętego Franciszka z Asyżu, świętego Bonawentury i świętego Jana Pawła II
}

Święty Franciszek z Asyżu, święty Bonawentura z Bagnoreggio i święty Jan Paweł II to grono osób, które łączy świętość życia oraz umiłowanie przyrody. Odczytywali ją jako księgę Boga, odkrywając w niej Jego wielkość i piękno. Wierni Pismu Świętemu, proponowali uznanie przyrody, by „z wielkości i piękna stworzeń poznać przez podobieństwo ich Stwórcę" (Mdr 13, 5) oraz uwielbiać Go za to dzieło. Spróbujemy wyjaśnić, co oznacza piękno wyciśnięte przez Boga w naturze.

\section{1. Święty Franciszek z Asyżu: „we wszystkim, co piękne,} widział Najpiękniejszego"

Jeden z biografów napisał o św. Franciszku: „«Radował się wszystkimi dziełami Boga» (Ps 91, 5) i poprzez ich widzialne piękno wznosił się

1 Dr hab. PawełWarchoł OFMConv, franciszkanin z Niepokalanowa. Wykłada na Papieskim Wydziale Teologicznym w Warszawie, w Instytucie Maryjno-Kolbiańskim „Kolbianum” w Niepokalanowie oraz w Wyższym Seminarium Duchownym Ojców Franciszkanów w Łodzi-Łagiewnikach. Autor wielu publikacji teologicznych oraz członek towarzystw naukowych, w tym Międzynarodowej Akademii Bożego Miłosierdzia. E-mail: pmmmawa@interia.pl. 
do ich ożywiającej Przyczyny i Racji Ostatecznej. We wszystkim, co piękne, widział Najpiękniejszego; szedł śladami zostawionymi w rzeczach i wszędzie znajdował Ukochanego, ze wszystkiego robiąc sobie drabinę, po której wstępował, aby spotkać Tego, który «jest cały godny pragnienia» (Pnp 5, 16). [...] Rozkoszował się ową źródlaną dobrocią w poszczególnych stworzeniach, jakby w potokach. Słysząc niebiańską muzykę w harmonii mocy i działań stworzonych przez Boga, zwyczajem proroka Dawida (Ps 148, 1n) zachęcał je słodko do wielbienia Boga"2.

Święty z Asyżu najlepiej uchwycił prawdę o pięknie pozostawionym w świecie, odczytał jego symbolikę i wyraził ją w sposób poetycki. Odczytał w przyrodzie miłość Boga do człowieka, na którą odpowiedzią powinien być pełen szacunek stworzenia do Stwórcy. Tomasz z Celano pisze, że szczególną miłością i śpiesznym uczuciem kochał „wszystko to, co zawie-

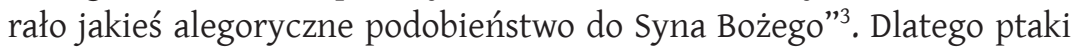
nazywał „szlachcicami wśród stworzeń”, bo mieszkają w czystym powietrzu i opiekuje się nimi Stwórca. Gdy głosił do nich kazania, wiedział, że potrzebują pożywienia, ale one były tak mu wdzięczne, że „nie ruszyły się z miejsca, dopóki nie zrobił nad nimi znaku krzyża i nie pozwolił im odlecieć"4 . Pośród ptactwa najbardziej przypadły mu do gustu skowronki, bo ukazywały cechy doskonałego zakonnika, zwracając uwagę na ich „odzienie, niewybredność w pokarmie i jednoczesną chęć przebywania na niebie i wyśpiewywania chwały Boga"5. One też go żegnały lotem i śpiewem, gdy odchodził do wieczności 3 października 1226 roku.

Przedmiotem podziwu Franciszka były pszczoły, wzbudzające zachwyt „techniką" przy zbieraniu i gromadzeniu surowców pokarmowych, subtelnością instynktu i zdolnością orientacji ${ }^{6}$. Rozrzewnienie powodują spotkania z owieczkami i barankami, ponieważ te wełniste zwierzęta

2 Św. Bonawentura, Życiorys większy świętego Franciszka z Asyżu, [w:] Wczesne źródła franciszkańskie, t. 1, zebrał i zred. S. Kafel, Warszawa 1981, s. 279.

3 Tomasz z Celano, Życiorys pierwszy św. Franciszka z Asyżu, [w:] Wczesne źródła franciszkańskie, t. 1, dz.cyt., s. 58.

4 Kwiatki św. Franciszka, tłum. L. Staff, Kraków 2013, s. 80.

${ }_{5}$ Por. Zbiór asyski, [w:] Wczesne źródła franciszkańskie, t. 2, zebrał i zred. S. Kafel, Warszawa 1981, s. 93.

6 Por. Życiorys drugiśw. Franciszka z Asyżu, [w:] Wczesne źródła franciszkańskie, t. 1, dz. cyt., s. 167. 
wprowadzały go w świat Jezusa i przypominały Jego pokorę i łagodność 7 . Nie gardził też robaczkami, przypominającymi Chrystusa w Jego męce ${ }^{8}$. Wzruszający był jego stosunek do roślin, gdyż - pisze Tomasz z Celano „braciom drwalom zabraniał ścinać całe drzewo, żeby miało nadzieję odrośnięcia na nowo. Ogrodnikowi kazał dokoła ogrodu pozostawiać nieuprawne obrzeże, ażeby na nim w swoich porach zieleń ziół i piękno kwiatów głosiły Ojca wszystkich pięknych rzeczy. W ogrodzie polecił wydzielić działkę na pachnące zioła i kwiaty, ażeby patrzącym przywoływały na pamięć błogość wiekuistą" ". Świat był dla niego radosną tajemnicą, którą podziwiał w zachwycie, oddając chwałę Bogu.

Historia z Gubbio, gdzie święty pojednał mieszkańców z wilkiem, dobrze o tym świadczy. Carlo Carretto zauważył, że „to, co jest niezwykłe w przygodzie wilka z Gubbio, to nie fakt, że on się oswoił, ale to, że oswoili się oni, mieszkańcy Gubbio, i że na spotkanie z wilkiem, który zbliżał się drżący z zimna i wygłodniały, wybiegli nie z widłami i toporami, ale z jadłem i ciepłym piciem. Na tym polega cud miłości: odkrycie, że całe stworzenie jest jednością zamierzoną przez Boga, który jest Ojcem; jeśli więc ty pojawiasz się, podobnie jak On, bez broni i pełen pokoju, stworzenie rozpoznaje cię i uśmiecha się do ciebie"10. Franciszkowa miłość ogarnia nie tylko ludzi, ale obejmuje w jednym symfonicznym objęciu wszystkie głosy wszechświata. Dzieło stworzenia jest dla niego „najprzejrzystszym zwierciadłem dobroci Bożej" ${ }^{11}$ i namacalnym sakramentem Jego chwały i dobroci.

Franciszek jak żaden inny święty był zakochany w przyrodzie. Kiedy spoglądał na zwierzęta i rośliny, ptaki i owady, śpiewał. Łączył się z całym stworzeniem, a głosząc kazania kwiatom, „zapraszał je do chwalby Pańskiej, tak jakby miały rozum"12. Dlatego pełen zdumienia Tomasz z Celano pytał: „Któż mógłby opisać nadzwyczajną jego miłość do wszystkich stworzeń

\footnotetext{
Por. Życiorys pierwszy św. Franciszka z Asyżu, dz. cyt., s. 58.

Por. Życiorys pierwszy św. Franciszka z Asyżu, dz. cyt., s. 59.

Życiorys drugi św. Franciszka z Asyżu, dz. cyt., s. 167.

C. Carretto, Ja, Franciszek, tłum. M. Kosiarska, Niepokalanów 1991, s. 38.

Życiorys drugi św. Franciszka z Asyżu, dz. cyt., s. 167.

Por. Życiorys pierwszy św. Franciszka z Asyżu, dz. cyt., s. 60.
} 
Bożych? Kto byłby w stanie wyrazić, z jak wielką radością dostrzegał w stworzeniach mądrość Bożą, potęgę i dobroć?"13.

Nawet w Oficjum o Męce Pańskiej Franciszek trzy razy zwraca się do stworzeń, by wezwać je do chwalby Boga za Jego cuda. Werset, który powraca najczęściej, zaczerpnięty jest z Ps 96, 11-12: „Niech weselą się niebiosa i raduje ziemia, niech poruszy się morze i to, co je napełnia; będą cieszyć się pola i wszystko, co na nich się znajduje"14.

Ponieważ większość modlitw i psalmów Franciszek wkłada w usta Chrystusowi, stąd sam Chrystus zaprasza stworzenia, by wspólnie uwielbiać Ojca. Takie spojrzenie pozwala stwierdzić, że patrzy on na stworzenia nie jako na obrazy Chrystusa, a raczej jako na współwielbicieli Ojca z Chrystusem. Zaiste trynitarne spojrzenie.

Piękno stworzenia Franciszek najpełniej wyraził w Pieśni słonecznej, gdzie do uwielbienia Boga zostają zaproszone słońce, gwiazdy, woda, powietrze i ogień oraz „matka ziemia, która [...] żywi i chowa, i rodzi różne owoce, barwne kwiaty i zioła"15. Franciszek nazywa je braćmi i siostrami. Jest pełen optymizmu i afirmacji dla świata materialnego, uznaje wewnętrzną godność przyrody i głosi konieczność pokoju oraz pojednania między ludźmi, jak też między człowiekiem a przyrodą.

W Pieśni słonecznej wszystkie stworzenia są przez Franciszka personifikowane, wskazując na bratersko-siostrzany związek z człowiekiem, podobnie jak one stworzonym przez Boga. One przybliżają piękno, jasność, blask, cenność, użyteczność, czystość, radość, krzepkość, moc. O słońcu wyśpiewuje: „Twoim, Najwyższy, jest wyobrażeniem, czyli jest Bożą hierofanią. Wszystkie jednak manifestują najwyższą świętość Transcendencji, wskazują ostateczny sens, za którym nie może istnieć żaden inny. Rzecz ciekawa. To najwznioślejsze dzieło poetyckie w całej historii języka włoskiego powstało w czasie jego choroby.

Święty Franciszek z Asyżu nie był filozofem czy teologiem, ale mistykiem, któremu stworzenie świadczyło o Bożej obecności. Czytając jego

13 Życiorys pierwszy św. Franciszka z Asyżu, dz. cyt., s. 59.

14 Por. Św. Franciszek, 1 Nieszpory, [w:] Święci Franciszek i Klara z Asyżu, Pisma, przekł. K. Ambrożkiewicz, Kraków-Warszawa 2002, s. 141.

15 Św. Franciszek z Asyżu, [w:] Święci Franciszek i Klara z Asyżu, Pisma, dz. cyt., s. 125. 
teksty i analizując jego postawę wobec przyrody, spotyka się człowieka, którego miłość do stworzeń i kosmiczne braterstwo są zrozumiałe w świetle jego wiary i w sposobie jej przeżywania. By napisać hymn uwielbienia przyrody, musiał mieć oczy, które chwytały piękno natury. Niczym malarz nie chciał przeinaczać natury, ale rozumieć jej charakter, który przemawia do duszy człowieka. Był artystą, który w naturze, czyli stworzonym dziele, odkrywał jego Twórcę.

W Pieśni słonecznej Franciszek nie zapomina też o człowieku, który odzwierciedla na wzór Jezusa piękno pod względem fizycznym i duchowym. Może też je odrzucić i zapomnieć o swym rodowodzie. W tym tkwi też jego paradoks, bo potrafi rozpoznać znaki Boże w przyrodzie, odsyłające do sensu ostatecznego, ale zapomina często o swojej świętości i Bożym obrazie, który nosi w sobie.

Całościowe spojrzenie świętego z Asyżu niesie ze sobą szereg ważnych postulatów etycznych. Uznanie wartości przyrody owocuje nową odpowiedzialnością i solidarnością. A jeśli refleksji o przyrodzie towarzyszy myśl o Bogu i człowieku, skutkuje ono próbą odbudowania sakralności przyrody. Dla Franciszka było czymś oczywistym, że kto kocha ludzi, ten kocha również stworzenie, bo Bóg obdarzył kosmicznym współczuciem wszystkie stworzenia.

\section{2. Święty Bonawentura: kontemplacja Boga w stworzeniach}

Nie byłoby pięknych strof, poświęconych śladom w przyrodzie odnajdywanym przez św. Franciszka, gdyby nie napisał ich św. Bonawentura. Jako teolog i filozof cenił naukę, zgłębiał kwestię stworzenia, postrzegając ją w świetle Trójcy Świętej. Był pewien, że można Ją rozpoznać w naturze, „o ile księga ta nie jest dla człowieka nieznaną lub oko człowieka nie jest zaćmione"16. Mówił zatem o dwóch warunkach wiedzy oraz świętości życia.

Franciszkański uczony potwierdzał rzeczywiście, że „każde stworzenie nosi w sobie strukturę trynitarną"17, realną tak, że mogłaby być

16 Św. Bonawentura, Quaest. disp. de Myst. Trinitatis, 1, 2, concl.

17 Franciszek, Encyklika Laudato si', 239. 
spontanicznie kontemplowana, gdyby spojrzenie człowieka nie było ograniczone.

Obecność Trójcy ukazuje poprzez stopnie analogii bytu, które są skutkiem powszechnego ładu panującego w świecie i stopnia zbliżania do Boga bytów stworzonych. Dlatego rozprawia o śladzie, obrazie i podobieństwie. Ślad Trójcy nosi każde stworzenie, podobnie jak bycie obrazem Boga należy do istoty każdego stworzenia. Zaznacza jednak, że w człowieku obraz Boży wypowiada się w „małej trójcy”, czyli w pamięci, rozumie i woli. Obraz nie ma w sobie nic statycznego, bo zaciera go grzech lub odnawia łaska. Dynamiczny charakter obrazu otwiera przed człowiekiem perspektywy rozwoju. Nie zakończy jej nawet śmierć, ponieważ wieczność usilnie pracuje nad wzorem podobieństwa obrazu Boga w duszy. Dlatego dopiero w wieczności będziemy nosić w sobie obraz człowieka niebieskiego - Chrystusa zmartwychwstałego, nowego Adama. Bycie człowiekiem oznacza zatem przejście od stanu Adama do stanu Chrystusa. Chrystus, zespoliwszy w swojej osobie bóstwo i człowieczeństwo, uzdolnił go do życia w Bogu.

Obecność obrazu Bożego w duszy sprawia, że człowiek niejako naturalnie ciąży ku Bogu, który jako dynamiczny prawzór przyciąga do siebie swoje obrazy. Dlatego człowiek jest otwarty na Boga i Go potrzebuje. Kontemplacja Boga staje się czymś naturalnym, a nie jest tylko szkołą nielicznych mistyków. Także kontemplacja przyrody jest czymś oczywistym, bo nie może abstrahować od ruchu na zewnątrz, spojrzenia, które z tajemnicy Boga zwraca się do świata.

Święty Bonawentura pisał: „Ślepcem jest ten, do kogo nie dociera blask bijący z rzeczy stworzonych. Głuchy jest ten, kto nie słyszy tak potężnego wołania. Niemy jest ten, kto nie wysławia Boga za te wszystkie skutki. Głupi jest ten, który mimo takich wskazówek nie zauważa pierwszej zasady. Otwórz więc oczy, nakłoń duchowe uszy, rozwiąż swe usta i przyłóż swoje serce, abyś we wszystkich stworzeniach zobaczył, dosłyszał, pochwalił, ukochał, uszanował, uwielbił i uczcił swojego Boga, by przypadkiem nie powstał przeciw tobie cały świat"18.

18 Św. Bonawentura, Droga duszy do Boga, [w:] Św. Bonawentura, Droga duszy do Boga i inne traktaty, tłum. S. C. Napiórkowski, Poznań 2001, s. 29. 
Bóg jest poznawalny przez człowieka za pośrednictwem stworzeń, bo one są Jego skutkami jako przyczyny i odbiciem Jego mądrości jako mistrza. To wznoszenie się poznania od stworzeń do Boga jest łatwe, bo stworzenia bardziej wiodą do Boga aniżeli do czegokolwiek innego. Wskazuje ono bardziej na intuicję, wnioskowanie bezpośrednie aniżeli na potrzebę żmudnego i drobiazgowego wywodu pośredniego ze skutku o przyczynie ${ }^{19}$. Święty Bonawentura potwierdza tym samym prawdę, którą wyraził Paweł w liście do Rzymian: „Jego potęga oraz bóstwo stają się widzialne dla umysłu przez Jego dzieła" $(1,20)$. Dlatego Stwórcę kontempluje się w dziełach.

Duchowość św. Franciszka i jego następców nie jest naiwna, mimo iż św. Maksymilian humanizował nawet narzędzia pracy, naśladując św. Franciszka z Asyżu: maszynę drukarską nazywał „babcią”, najsilniejszy motor elektrowni „Ursusem”, a jego poprzednika „dziadkiem”. Jednym ze skutków takiego podejścia do narzędzi pracy była większa o nie troska. Były one włączone w działalność na większą chwałę Boga ${ }^{20}$.

Aby rzeczywiście zbliżyć się do Boga, coraz bardziej upodobnić się do obrazu Jego Syna, należy poważnie wglądać w swoje wnętrze i kontemplować piękno stworzonej natury. Wtedy świat zewnętrzny i wewnętrzny wciąga człowieka w wir życia Bożego, ukazując miłość Stwórcy ogarniającą wszystko i wszystkich. Człowiek bowiem nie jest bytem statecznym, lecz urzeczywistnia paschalny proces zmierzający do przeobrażenia ludzkiej osoby, a poprzez nią także świata.

\section{Jan Paweł II: „odnajdywał we wszystkim jakiś ślad swej Istoty, swej pełni"}

Od początku pontyfikatu Jan Paweł II był żywo przejęty postacią św. Franciszka z Asyżu. Nieobca mu była też teologia św. Bonawentury.

19 Por. T. C. Niezgoda, Poznaniei jego drogido Boga według św. Bonawentury, [w:] Św. Bonawentura. Życie i myśl, red. S. C. Napiórkowski, E. I. Zieliński, Niepokalanów-Warszawa 1976, s. 123.

20 L. B. Dyczewski, Święty naszych czasów. Zasadnicze rysy duchowości i działalności św. Maksymiliana M. Kolbego, [w:] Błogosławiony Maksymilian M. Kolbe. Dokumenty, artykuły, opracowania, red. J. R. Bar, Niepokalanów 1974, s. 242-255. 
Na tę specyfikę miał wpływ kontakt z franciszkanami. Do dzisiaj znajduje się tabliczka na ławce w ich kościele, gdzie modlił się Wojtyła.

Przyszły papież wiedział, że święty z Asyżu zapisał się znacząco w historii Kościoła i świata. Dał się też poznać jako miłośnik przyrody, którą się zachwycał i którą podziwiał, bo widział w niej ślady Boga.

Kiedy 29 listopada 1979 roku ogłosił św. Franciszka patronem ekologów, napisał, że „[...] słusznie zalicza się [go] między tych świętych i słynnych mężów, którzy odnosili się do przyrody jako cudownego daru udzielonego przez Boga rodzajowi ludzkiemu. Albowiem on głęboko odczuł w szczególny sposób wszystkie dzieła Stwórcy i natchniony Bożym duchem wyśpiewał ową najpiękniejszą «Pieśń stworzeń», przez które, szczególnie przez brata słońce, brata księżyc i siostry gwiazdy niebieskie, oddał należne uwielbienie, chwałę, cześć i wszelkie błogosławieństwo najwyższemu i dobremu Panu..."21. On bowiem ukazał postawę pełną miłości stworzenia $^{22}$ i „pełną miłości świata ${ }^{23}$.

Podobnie w poemacie Tryptyk rzymski odniósł się do przyrody. W pierwszej części (Strumień) nie wymienia co prawda św. Franciszka ani św. Bonawentury, ale zadziwia się pięknem natury i jego tajemnicą, ukazując - jak pisze Marek Skwarnicki - „metafizykę przyrody”24. Wojtyła dostrzega związek stworzenia z Odwiecznym Słowem, gdyż „ogarnia wszystko, powołując do istnienia z nicości nie tylko na początku, ale wciąż" ${ }^{25}$. Słowo jest przyczyną sprawczą wszystkiego, co istnieje. Bóg zatem - „pierwszy Widzący - widział, odnajdywał we wszystkim jakiś ślad swej Istoty, swej pełni" ${ }^{26}$. Więcej: widział, że wszystko, co wyszło z Jego ręki, jest „prawdziwe, dobre i piękne”27. To najgłębsza metafizyka,

${ }^{21}$ Jan Paweł II, List Inter Santos, 29 XI 1979 r., [w:] Jan Paweł II, Dzieła zebrane, t. 3 Listy, Kraków 2007, s. 625.

22 Jan Paweł II, Serce Jezusa, z którego pełni wszyscy otrzymali. Rozważanie przed modlitwą „Anioł Pański”, 13 VI 1986 r., „L’Osservatore Romano” wydanie polskie 8 (1986), s. 9.

${ }^{23}$ Por. Św. Franciszek z Asyżu, Pieśń słoneczna, [w:] Święci Franciszek i Klara z Asyżu, Pisma, dz.cyt., s. 283.

${ }_{24}$ M. Skwarnicki, Poetycka droga Papieża Wojtyły, [w:] K. Wojtyła, Poezje, dramaty, szkice/ Jan Paweł II, Tryptyk rzymski, Kraków 2004, s. 20.

25 Jan Paweł II, Tryptyk rzymski, [w:] K. Wojtyła, Poezje, dramaty, szkice..., dz. cyt., s. 511.

26 Jan Paweł II, Tryptyk rzymski, dz. cyt., s. 511.

27 Jan Paweł II, Tryptyk rzymski, dz. cyt., s. 512 
odwołująca się do Biblii i teologii św. Bonawentury, św. Franciszka i własnego doświadczenia, ujęta w poetyckiej formie.

Wojtyła tłumaczy, że pięknem zadziwia się człowiek, ale nie przyroda, dając mu pierwszeństwo wśród wszystkich stworzonych przez Stwórcę bytów. Pyta: „Dlaczego o tym właśnie jedynym dniu powiedziano: „Widział Bóg, że wszystko, co uczynił, było bardzo dobre?"28. W tym dniu został stworzony człowiek, umiłowany i podniesiony w hierarchii bytów przez Boga tak, że nic z nim nie może się równać. Doskonałość stworzenia człowieka potwierdzi przez Boga przyjęcie ludzkiego ciała.

Wojtyła zadaje kolejne pytanie: „Czemu temu nie przeczą dzieje? Choćby nasz wiek dwudziesty! I nie tylko dwudziesty!"29. Daje do zrozumienia, że między stworzeniem a rzeczywistością jest rozziew. Człowiek przeczy samemu sobie, bo jest wielki i słaby, kocha i nienawidzi, buduje wielkie cywilizacje i je burzy, dokonuje wspaniałych odkryć z dziedziny nauki i techniki i uśmierca ludzkie życie, tworzy piękne dzieła sztuki i organizuje bratobójcze walki, dba o ekologię ziemi i niszczy równowagę natury, zachwyca się światem zwierząt i zabija najbardziej niewinnych, szuka życia na nowych planetach i przygotowuje światu zagładę. Jest świętym i grzesznikiem, zdolnym do największych poświęceń i bezwzględnym dyktatorem, altruistą i egoistą, wynalazcą i niszczycielem, budowniczym pokoju i terrorystą, zauważającym na piasku ślady wieczności i walczącym z Bogiem w ustawach parlamentarnych i naukowych dyskusjach... W swojej wolności ma moc robienia z siebie wszystkiego: być prawie diabłem i prawie Bogiem?

„Cóż za monstrum jest tedy człowiek? Cóż za osobliwość, co za potwór, co za chaos, co za zbieg sprzeczności, co za dziw! Sędzia wszechrzeczy bezrozumny robak ziemny; piastun prawdy - zlew niepewności i błędu; chluba i zakała wszechświata. Kto rozplącze ten zamęt? [...] Cóż tedy poczniecie wy, o ludzie, którzy przyrodzonym rozumem dochodzicie waszej prawdziwej istoty? [...] Umilknij [...] naturo: dowiedz się, że człowiek nieskończenie przerasta człowieka"30 - pisze Blaise Pascal.

28 Jan Paweł II, Tryptyk rzymski, dz.cyt., s. 514.

29 Jan Paweł II, Tryptyk rzymski, dz. cyt., s. 514.

30 B. Pascal, Myśli oraz rozprawa o kondycjimożnych. Modlitwa o dobry użytek chorób. Rozprawa o namiętnościach miłości, tłum. T. Żeleński Boy, Kraków 2003, s. 111. 
Ale mimo całej gamy sprzecznych sądów o człowieku „żaden wiek nie może przesłonić prawdy o obrazie i podobieństwie"31 - konkluduje papież. Człowiek stał się uprzywilejowanym przedmiotem miłości Boga, wyłącznym stworzeniem ziemskim, które Bóg chciał dla niego samego ${ }^{32}$. Człowiek w oczach Boga nigdy nie został przekreślony. Pozostaje przedmiotem Jego miłości. Co prawda nie jest w pełni ukształtowany, ale nieustannie się rozwija, zmagając się ze swoimi słabościami z dnia na dzień i wytrwale dążąc do wyższej doskonałości osobistej i większej aktywności osobistej, bo w tej perspektywie objawia się jego dynamika i duchowy rozwój.

Fakt bycia człowiekiem jest ustawicznym procesem stawania się i uczłowieczania. Nie jest to proces zakończony, ponieważ ludzkość nie doszła jeszcze do kresu moźliwości. Nadal trwa ewolucja sfery cielesnej i duchowej, chociaż czasem o tym zapominamy. Tę jedność człowiek odnajduje w Bogu, bo „wszechświat wyłonił się ze Słowa i do Słowa też powraca”33.

Twórczość poetycka papieża jest w pewnym stopniu inspirowana przemyśleniami Franciszka i Bonawentury, jest dociekaniem tajemnic życia i śmierci, obecności Boga w naturze, w ludziach jako rzeczywistości sakralnej, bez względu na wyznawaną wiarę. Jest też zapisem olśnień lirycznych nad pięknem i prawdą, będących odblaskiem boskości w naturze. Pozwalają one zrozumieć je jako dar Boży i rozwijać wizję „cywilizacji życia".

Potwierdzeniem tak rozumianej rzeczywistości są słowa, które papież wypowiada do ludzi morza w Gdyni i w których przejawia się wręcz pierwotna, franciszkańska fascynacja przyrodą: „[...] Trzeba, ażeby na tym miejscu odezwał się kantyk całego stworzenia, które oddaje chwałę Stwórcy. Trzeba, ażeby przemówiły głosem chwały rzeki i morze. A przede wszystkim ta rzeka, która nieopodal stąd kończy swój bieg, uchodząc do Bałtyku. Wisła - rzeka wszystkich ziem polskich, rzeka naszych dziejów. Od stuleci - zanim jeszcze imię Polski pojawiło się w annałach historii - ona już toczyła swoje wody od Karpat, od śląskich Beskidów, gdzie ma

\footnotetext{
31 Jan Paweł II, Tryptyk Rzymski, dz.cyt., s. 514.

32 Sobór Watykański II, konst. Gaudium et spes, 24.

33 Jan Paweł II, Tryptyk Rzymski, dz. cyt., s. 514.
} 
swe źródła, aż dotąd. Rzeka, milczący świadek życia pokoleń, ich rodzenia się i umierania. Ich twórczych wysiłków związanych z gruntowaniem wszystkiego, co Polskę stanowi. Ich zmagań, czasem zmagań na śmierć i życie, ażeby utrzymać i zabezpieczyć to, co ojczyste, co jest wspólnym dorobkiem i wspólnym dziedzictwem. Wisła... Bądź błogosławiona, rzeko! Ucz nas twoją wiernością dla naszej ziemi błogosławić Ojca, który jest w niebie. I bądź błogosławione ty, morze, które jesteś przeznaczeniem Wisły, naszej rzeki - tak jak królestwo Boże jest przeznaczeniem ludzi żyjących na tej ziemi"34.

Papież daje przykład, jak zachować żywe uczucia „braterstwa” ze wszystkimi rzeczami, dobrymi i pięknymi, które stworzył wszechmocny Bóg i odczytywania Jego mądrości zawartej w ich śladach. Dzieła natury wiodą do Boga jako Stwórcy i Ojca wszystkich rzeczy. Stwarzając, Bóg naznaczył je swą świętością.

\section{Konsekwencje „metafizyki przyrody”}

Święty Franciszek, święty Bonawentura i święty Jan Paweł II przekonują, że przyroda uświadamia prawdę, iż ciążymy ku nieskończoności. Urzeczywistni się to dopiero w niebie, kiedy dusza stanie się podobna Bogu, ujrzy Go i pokocha oraz zrozumie wszystkie znaki, przez które przemawiał Bóg do niej na ziemi.

\section{1. Natura udziela lekcji wiary}

Na podstawie śladów Stwórcy zostawionych w naturze św. Franciszek, św. Bonawentura i św. Jan Paweł przypominają, że Bóg jest Pierwszym Bytem i Racją Ostateczną. W świecie, w którym eliminuje się Boga, a ludzie w Niego nie wierzą, ślady Boga w stworzeniu przypominają, że nawet natura udziela lekcji wiary. Wiara w Boga Stwórcę umożliwia człowie-

34 Jan Paweł II, Homilia w czasie Liturgii Słowa skierowana do Ludzi morza, 11 VI 1987 r., [w:] Jan Paweł II, Dzieła zebrane, t. 9 Homilie i przemówienia z pielgrzymek - Europa, cz. 1 Polska, Kraków 2008, s. 367. 
kowi doświadczenie duchowe, które włącza go w kosmos i sprawia, że czuje się jego cząstką. Człowiek jest tym, który doświadcza kosmicznego wymiaru życia.

Święty Franciszek, święty Bonawentura i święty Jan Paweł II pojmują świat jako „sakrament chwały Boga”. Według nich wszechświat swoim istnieniem chwali Boga. Panowanie Boga nad nimi jest łaskawe, opiekuńcze i ojcowskie. Przyroda jest dana człowiekowi jako przedmiot podziwu i kontemplacji i jako wielkie zwierciadło świata. Odbija się w nim przymierze Stwórcy ze swoim stworzeniem, którego centrum od początku znajduje się w człowieku, stworzonym wprost na obraz Stwórcy. Przyroda prowadzi do ostatecznej przyczyny, jaką jest Bóg i Stwórca wszechświata. Nie jest to tłumaczenie darwinowskie ani neodarwinowskie, lansowane w czasach współczesnych, ale odwołujące się do Rozumu i Mądrości.

Mistyka św. Franciszka, wydobywająca wspólną wartość braterstwa, w której wszyscy dzielą jednaki los, jest podpowiedzią dla tych, którzy nie wierzą. Ojciec, który stworzył niebo i ziemię, a Jego ślady odnajduje się w stworzeniach, przypomina, że wszyscy i wszystko tworzą rodzinę, czyli bratersko-siostrzaną wspólnotę z Ojcem i dalszymi krewnymi, braćmi kosmicznymi. Każdy z członków „rodziny Franciszka” pragnie zaświadczyć o swym synostwie lub siostrzaności w obliczu Ojca.

Ślady Boga pozostawione w przyrodzie pozwalają dostrzec bezinteresowną miłość, a w konsekwencji zachwyt nad tajemnicą istnienia i pozostawionego piękna. Rzecz w tym, by umieć usłyszeć, czyli mieć umiejętność rozpoznawania znaków i ukrytych w nich sensów.

Bóg dał ludziom ziemię, aby ich utrzymywała. Dla Biedaczyny z Asyżu stworzenia są darami Bożymi, za które trzeba dziękować Stwórcy. Należy ich strzec z poczuciem wdzięczności wobec ich Stwórcy. Z przyrodą nie można robić tego, co się podoba. Franciszkowy stosunek do stworzenia był zgłębiany przez papieży, aby rozwój człowieka uwzględniał poszanowanie świata przyrody i brał pod uwagę naturę każdego bytu oraz ich wzajemne powiązanie w uporządkowany system. Dlatego zdolność człowieka do przekształcenia rzeczywistości powinna być rozwijana na podstawie pierwotnego przeznaczenia rzeczy, wyznaczonego jej przez Boga. 


\section{2. Człowiek „obraz Boży”}

Intuicje i przemyślenia św. Franciszka, św. Bonawentury i św. Jana Pawła II znajdują uzasadnienie w Księdze Rodzaju. W pierwszym opisie stworzenia, zwanym jahwistycznym, Bóg, powołując do istnienia wszechświat, na samym końcu stwarza człowieka, natomiast w wersji kapłańskiej czyni to na samym początku. Mimo to teksty te uświadamiają, że człowiek jest najważniejszy wśród bytów, ponieważ odwołują się one do jego godności i wielkości. Stoi bowiem na szczycie piramidy stworzeń. To nie tylko jego fizyczne wywyższenie, ale misja, jaką ma pełnić, czyli pogłębić rozumność i dobroć dzieła Bożego; być starszym bratem niższych stworzeń; współtworzyć i troszczyć się o dzieło stworzenia; być jego opiekunem i stróżem.

Chociaż w hierarchii bytów człowiek otrzymuje wyższą pozycję, to jednak podobnie jak zwierzęta został ulepiony z prochu ziemi - adama. Jest więc „ziemianinem”, istotą związaną z ziemią i pokrewną zwierzętom. Więcej, został stworzony, gdy Bóg zakończył stwarzanie zwierząt, a po stworzeniu człowieka dokonał swogo dzieła. Może poddać się działaniu najniższych instynktów zwierzęcych, może też pragnąć zająć miejsce Boga, mimo iż między człowiekiem i jego Stwórcą istnieje fundamentalna różnica, która nie pozwala człowiekowi zająć miejsca Boga.

Przyroda zatem, jak ją odczytywali św. Franciszek, św. Bonawentura i św. Jan Paweł II, podpowiada, że Bóg jest największy. Człowiek jest tylko „ukształtowany na obraz i podobieństwo Boże”. Dlatego tylko z Jego pomocą może znaleźć sens swego istnienia, czyli działania oraz ostatecznego przeznaczenia. Prawdziwa wielkość człowieka nie polega zatem na tym, że jest on „mikrokosmosem”, streszczającym w sobie to, co duchowe i cielesne, widzialne i niewidzialne, ale na tym, że jest przede wszystkim osobą na „obraz Boży”, wezwaną do odpowiedzialnego kształtowania swej natury i odpowiadania na upodobanie Stwórcy. To stwórcze dzieło Boga osiągnęło taką pełnię, jakiej nie otrzymało żadne inne ze stworzeń.

Zarówno św. Franciszek, św. Bonawentura, jak i św. Jan Paweł II chętnie mówią o pięknie stworzenia oraz wieńczącej je świętości. Dostrzegają ją w naturze i w duszy ludzkiej. Dzięki temu człowiek stoi najbliżej Boskiego Prawzoru, tym samym jest doskonalszy, ponieważ piękno duszy ludzkiej 
gwarantuje łaska Pańska: zbliża ona człowieka do Bytu Boskiego, przewyższając całą harmonię naturalną. Nie na darmo Pan postawił człowieka na początku swoich dróg i spoczął w nim u kresu swoich poczynań, by upodobnił się do Niego, swego Stwórcy.

Piękno, jeśli prowadzi do Boga, nie wywołuje przyjemności zmysłowej, nie wzbudza żądzy posiadania, lecz wywołuje zachwyt dla czynu Stworzyciela, który pozwala w nim partycypować. Dzięki niemu człowiek może z godnością i pożytkiem uczestniczyć w rozwoju i utwierdzaniu się w nowej wrażliwości duchowej, która umieszcza człowieka w świecie, z postawą bardziej kontemplacyjną, a mniej instrumentalną i manipulacyjną i otwiera mu przestrzenie ludzkiego doświadczenia i realizacji w dzisiejszych czasach.

\section{3. Natura i liturgia w pisarstwie i poezji}

Zachwyt św. Franciszka z Asyżu nad przyrodą i pozostawionymi w niej śladami Boga nie był obcy polskim pisarzom i poetom. W okresie Młodej Polski taki zachwyt wyrazili Jan Kasprowicz, Stanisław Żeromski, Władysław Reymont i Leopold Staff. Dla nich przyroda jest uwielbieniem Boga, co jest też przedmiotem refleksji, którą podejmują współcześni filozofowie religii ${ }^{35}$. Na przykład Władysław Reymont pisze w Chłopach o przedziwnej relacji pomiędzy naturą a sacrum. Występuje ona w każdej porze roku. Spośród wielu, warto odnieść się do wiosny, kiedy wstaje kwietniowy dzień, gdy „mgły się zakolebały z nagła [...], biły w czarne pola albo zasię, kiedy dymy kadzielne wionęły swym przędziwem ku niebu" ${ }^{36}$. Natura naśladuje liturgię. Wstające słońce wygląda tak, „kieby dobrodziej ma wznieść na podniesienie hostię przenajświętszą”. Głos skowronka natomiast „wystrzelił z nagła [...] jako ta z czystego srebra sygnaturka”37. Dalej autor dopowiada, że słońce się „,wychylało z przepaści i kieby tę ogromną, złocistą i rozgorzałą ogniami patenę wynosi-

35 Por. R. Otto, Świętość. Elementy irracjonalne w pojęciu bóstwa i ich stosunek do elementów racjonalnych, tłum. B. Kupis, Warszawa 1968; Z. Zdybicka, Człowiek i religia, Lublin 1978.

36 W. S. Reymont, Chłopi, t. 3, Warszawa 1976, s. 70.

37 W. S. Reymont, Chłopi, t. 3, dz.cyt., s. 8. 
ły Boże, niewidzialne ręce nad sennymi ziemiami [...], a wszystko jakby $\mathrm{z}$ nagła padło w proch przed majestatem i zamilkło przywierając oczy niegodne" ${ }^{38}$. Reymont podkreśla udział natury w nabożeństwie: mgły „kiej dymy z trubularzów biły z łąk ku rozzłoconemu niebu, a ptactwo i stworzenie wszelkie uderzało w wielki krzyk śpiewań,jakby w ten pacierz serdecznych dziękowań”. Słońce natomiast „urastało wciąż [...] coraz wyżej, i wielkie gorejące, ciepłe kiej to święte oko miłosierdzia Pańskiego - brało

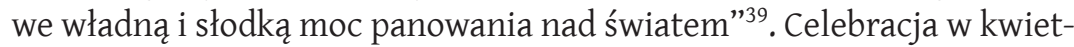
niowy poranek jest tak samo uroczysta jak w kościele.

Reymont posługuje się symboliką Eucharystii i tworzy paralelę z tą,jaka odbywa się w „kościele kosmosu” na ofiarniczym ołtarzu ziemi. Opisuje przebieg mszy świętej w lipieckim kościele, w którym bliskość Boga ukazuje się wiernym pod postacią hostii. Podobne doświadczenie ma miejsce w naturze, która doświadcza radosnej bliskości swojego Stwórcy, jak człowiek, gdy poddaje się oddziaływaniu sakramentu Eucharystii.

Naturę po franciszkańsku czytał też Leopold Staff, tłumacz Kwiatków św. Franciszka.W swojej poezji podkreślał, że w niedzielę, kiedy cała wieś modli się na sumie, odprawiana jest msza święta na stawie dla znieruchomiałych w modlitewnej pokorze przybrzeżnych rogoży ${ }^{40}$. Podobne msze u Staffa odprawiaja morze, słońce, noc, wieczorny krajobraz: te „eucharystie" natury są hołdem złożonym Stwórcy. Dzięki kontemplacji przyrody człowiek przeżywa zarówno „dalekość” i „bliskość” Boga: przezksięge natury, jej znaki i szyfry tęskni za Tym, który jest nieogarniony, a jednocześnie bliski, bo przenika wszystko i wszystkich. Natura umożliwia duchową rozkosz odkrywania Boga. W swym liryzmie Staff umiejętnie odczytuje dwie księgi: Pismo Święte oraz księgę natury. W tej drugiej znajduje znaki, poprzez które Stwórca przemawia do stworzenia.

$$
*^{*} *
$$

Nie sposób przejść obojętnie wobec przyrody i nie dostrzec ukrytej w niej mądrości i znaków. Prowadzą one do odkrycia Pierwszej Przyczyny,

38 W. S. Reymont, Chłopi, t. 3, dz.cyt., s. 10.

39 W. S. Reymont, Chłopi, t. 3, dz.cyt., s. 10.

40 L. Staff, Msza wodna, [w:] Wiersze zebrane, Warszawa 1955, t. 5, s. 146. 
Boga i Stwórcy. Skłaniają do refleksji i podpowiadają cel i sens. Dlatego św. Franciszek, św. Bonawentura i św. Jan Paweł II, obcując z przyrodą, w której dostrzegali ślady Boga, przybliżali się do Źródła Piękna. Tę lekcję podają innym: by w księdze natury uczyć się odczytywać znaki i szyfry Stwórcy, które mówią o Jego obecności. 


\section{Summary}

Ślady Boga w przyrodzie w pismach świętego Franciszka z Asyżu, świętego Bonawentury i świętego Jana Pawła II

Święty Franciszek z Asyżu, święty Bonawentura z Bagnoreggio i święty Jan Paweł II to grono osób, które łączy świętość życia oraz umiłowanie przyrody. Odczytywali ją jako księgę Boga, odkrywając w niej Jego wielkość i piękno. Wierni Pismu Świętemu, proponowali uznanie przyrody, by „z wielkości i piękna stworzeń poznać przez podobieństwo ich Stwórcę" (Mdr 13,5) oraz uwielbiać Go za to dzieło. Dla wierzących i niewierzących piękno wyciśnięte przez Boga w naturze dowodzi Jego istnienia i pozwala patrzeć na świat w perspektywie wieczności.

Odczytanie śladów Boga w przyrodzie adresowane jest dla wszystkich ludzi, gdyż razem tworzą rodzinę, bratersko-siostrzaną wspólnotę z Ojcem i dalszymi krewnymi, braćmi kosmicznymi. Ślady Boga pozostawione w przyrodzie pozwalają dostrzec bezinteresowną miłość, a w konsekwencji zachwycić się nad tajemnicą istnienia i pozostawionego piękna. Rzecz w tym, by umieć usłyszeć, czyli mieć umiejętność rozpoznawania znaków i ukrytych w nich sensów.

Słowa kluczowe: ślad, przyroda, Bóg, natura, piękno, księga, znak

The traces of God in nature in the writings of saint Francis of Assisi, saint Bonawentura and saint John Paul II

St. Francis of Assisi, St. Bonaventure of Bagnoregio and St. John Paul II form a group of people who share devotion for the sanctity of life and love of nature. They saw and read life and nature as a living book of God, discovering grandeur and beauty of creation. Faithful to Scripture, they proposed appreciation of nature because "For by the greatness of the beauty, and of the creature, the Creator of them may be seen, so as to be known thereby" (Wis 13: 5), and glorify Him for this work. For believers and nonbelievers beauty placed by God in nature proves His existence and allows the person to look at the world in the perspective of eternity.

Reading the signs of God in nature is addressed to all people, because together we form a family, a brotherly sisterly communion with the Father and our universal relatives. God left traces in nature to provide an insight into His selfless love and, consequently, to marvel at the mystery of existence and its beauty. The point is to be able to hear or have the ability to recognize the signs and hidden meanings which speak to us of this.

Keywords: traces, nature, God, creatures, beauty, book, signs 


\section{Bibliografia}

Błogosławiony Maksymilian M. Kolbe. Dokumenty, artykuły, opracowania, red. J. R. Bar, Niepokalanów 1974.

Św. Bonawentura, Quaest. disp. de Myst. Trinitatis.

Św. Bonawentura, Droga duszy do Boga i inne traktaty, tłum. S. C. Napiórkowski, Poznań 2001.

Carretto C., Ja, Franciszek, tłum. M. Kosiarska, Niepokalanów 1991.

Franciszek, Encyklika Laudato si'.

Święci Franciszek i Klara z Asyżu, Pisma, przekł. K. Ambrożkiewicz, KrakówWarszawa 2002.

Jan Paweł II, Dzieła zebrane, t. 9 Homilie i przemówienia z pielgrzymek - Europa, cz. 1 Polska, Kraków 2008.

Jan Paweł II, Dzieła zebrane, t. 3 Listy, Kraków 2007.

Jan Paweł II, Serce Jezusa, z którego pełni wszyscy otrzymali. Rozważanie przed modlitwą „Anioł Pański”, 13 VI 1986 r., „L'Osservatore Romano” wydanie polskie 8 (1986), s. 9.

Kwiatki św. Franciszka, tłum. L. Staff, Kraków 2013, s. 80.

Otto R., Świętość. Elementy irracjonalne w pojęciu bóstwa i ich stosunek do elementów racjonalnych, tłum. B. Kupis, Warszawa 1968.

Pascal B., Myśli oraz rozprawa o kondycji możnych. Modlitwa o dobry użytek chorób. Rozprawa o namiętnościach miłości, tłum. T. Żeleński Boy, Kraków 2003, s. 111.

Reymont W. S., Chłopi, t. 3, Warszawa 1976.

Sobór Watykański II, Konstytucja Gaudium et spes.

Staff L., Wiersze zebrane, Warszawa 1955, t. 5.

Św. Bonawentura. Życie i myśl, red. S. C. Napiórkowski, E. I. Zieliński, NiepokalanówWarszawa 1976.

Wczesne źródła franciszkańskie, t. 1, zebrał i zred. S. Kafel, Warszawa 1981.

Wczesne źródła franciszkańskie, t. 2, zebrał i zred. S. Kafel, Warszawa 1981, s. 93.

Wojtyła K., Poezje, dramaty, szkice/ Jan Paweł II, Tryptyk rzymski, Kraków 2004.

Zdybicka Z., Człowiek i religia, Lublin 1978. 